DOI: $10.31866 / 2410-1915.21 .2020 .208240$

UDC 316.73:338.48(100)

\title{
INTERNATIONAL TOURISM AS A FORM AND MEANS OF THE DIALOGUE OF CULTURES
}

\author{
Serhii Krasovskyi
}

Lecturer, ORCID: 0000-0001-9314-7594,krasovskiis@gmail.com, Kyiv National University of Culture and Arts, 36, Ye. Konovaltsia St., Kyiv, 01133, Ukraine

\section{For citations:}

Krasovskyi, S. (2020). International Tourism as a Form and Means of the Dialogue of Cultures. Culture and Arts in the Modern World, 21, 105-115. https://doi.org/10.31866/2410-1915.21.2020.208240.

The purpose of the article is to identify the role and importance of international tourism in the process of the dialogue of cultures. The research methodology is based on the application of general scientific methods, as well as activity-based and systembased approaches, which made it possible to study scientific publications on this issue. The scientific novelty lies in the analytical evaluation of the role and importance of international tourism in the process of intercultural dialogue. In particular, it is emphasized that international tourism in today's globalized world is becoming one of the most effective ways of expanding the interaction of the representatives of different cultures, a practical method of principles of the cooperation at the international level. Conclusions. International tourism, as a peculiar means of human inculturation, clearly demonstrates the dominant features of contemporary world processes, including multiculturalism, mass displacement of people, creation of new cultural communities, cultural integration and mobility. These processes not only make possible regular contacts between the representatives of different cultures, but also determine the features of intercultural communication. Effectively responding to rapid social changes, constantly increasing human needs, offering new ways to meet them, international tourism becomes both a factor and a kind of intercultural communication, a form and means of dialogue between cultures. International tourism effectively implements the function of interpersonal communication, the interaction of carriers of certain cultural values and ideological stereotypes. International tourism builds relationships of trust and understanding, coordinates the shared values of different cultural communities, and, therefore, is a tool for establishing the dialogue between cultures. The above mentioned allows us to state that the effectiveness of international tourism, which today is perceived not only as a way of providing leisure activities of a person, but involves relaxation and self-realisation of an individual, his adaptation to the changing realities of the world.

Keywords: culture; dialogue of cultures; international tourism; intercultural communication. 


\section{Introduction}

The White Paper on Intercultural Dialogue "Living together in equality and dignity", approved by the Council of Europe Ministers of Foreign Affairs at their $118^{\text {th }}$ Ministerial Session (Strasbourg, 7 May 2008), emphasizes that "the democratic governance of cultural diversity should be adapted in many aspects; intercultural competences should be taught and learned; spaces for intercultural dialogue should be created and widened; and intercultural dialogue should be taken to the international level" ("Bila knyha", 2010, p. 4). The recognition of the importance of the cultural interaction, which would facilitate the dialogue between the peoples based on the understanding of the role of culture in the life of each nation and world civilization, generally demonstrates the understanding of the irreversibility of most of the dominant sense guidelines and principles of the functioning of various cultures in the globalized world. The formation of the latter is less due to the social and political transformations than to the active actions of people, in particular their free movement, which, though pursuing different goals at different times, has always contributed to the discovery of new lands and knowledge of the cultures of other peoples.

Complex and contradictory relations between nations in the contemporary world require the search for adequate means of motivating people's cognitive interests as a stimulus to preserve cultural and historical heritage, solve cross-cultural conflicts, and create a positive image of the country and its population in the world. Not the least role in this is played by international tourism as a kind of means of human inculturation, a specific form of the organization of social and cultural reality.

The importance of international tourism in the process of cultural dialogue is confirmed by the expansion of the range of scientific research in the framework of turismology - a science that studies various aspects of tourism, in particular social and cultural, and is considered to be one of the promising areas of theoretical research. Philosophers, sociologists, culturologists and representatives of other fields of knowledge study tourism not only as an element of communication, including international N. Bereznitckaia (1999), S. Bogdanova (2005), A. Lyzin, (2005), E. Moshniaga (2011), but also as a tool for dialogue of cultures and civilizations, as a way of cultural interaction in the contemporary world O. Alkhutov (2009); L. Apanasiuk (Apanasiuk \& Egorova, 2017), O. Kostriukova (2012), etc. Thus, N. Bereznitckaia (1999) carried out a cultural analysis of the communicative potential of tourism, which gave the author the opportunity to consider tourism as a form of communication. S. Bogdanova (2005) considered specific communication technologies in tourism. A. Lyzin (2005) in her work discovered and characterized the features of intercultural communication. E. Moshniaga (2011) identified the main regularities of the development of intercultural communication in the system of international tourism and the features of their manifestation in the context of globalization and opposing trends to preserve cultural diversity and dialogue of cultures. The work of A. Alkhutov (2009) is associated with the cultural analysis of trends in the development of cultural tourism, studying it as 
a "mechanism" that stimulates the formation of the intercultural interaction, which affects the creative abilities of a person, using it as a form of "people's diplomacy". O. Kostriukova (2012) studied tourism as an effective tool for the dialogue of cultures and civilizations in the contemporary world. L. Apanasiuk (Apanasiuk \& Egorova, 2017) studied the international tourism activities in the development of the intercultural communication, O. Kostriukova (2012) studied tourism as an effective tool for the dialogue of cultures and civilizations in the contemporary world.

\section{Purpose of the article}

The purpose of the article is to identify the role and importance of international tourism in the process of the dialogue of cultures.

The research methodology is based on the application of general scientific methods, as well as activity-based and system-based approaches, which made it possible to study the scientific publications on this issue.

\section{Main research material}

Communication across cultures has been understood by various researchers at different times as a way of preserving cultural diversity, overcoming the tragic incompatibility of cultures as a means of world culture formation and establishment of the internationalism. In particular, M. Bakhtin considers it as a form of communication between different cultures, stating that "culture exists there, where there are two (at least) cultures", and further: "the self-consciousness of a culture is a form of its being on its borders with other culture" (Bibler, 1991, p. 85). In fact, all of M. Bakhtin's reflections on culture, as emphasized by V. Bibler (Bibler, 1991), have a single meaning (idea) - dialogue, and all reflections on a dialogue also have one meaning (idea) - culture (Osadchii, 2001). Dialogism in the context of culture (being of culture ... the meeting of cultures ... mutual understanding of cultures), according to V. Bibler, is an almost universal phenomenon, an ontological basis, and the "dialogic fabric of the human life" - when culture is fully developed in interaction, it returns to its "borders" and then re-enters into interaction (Osadchii, 2001).

Taken into consideration that any culture is both a carrier of a system of values that have a general civilizational meaning and a system of values that have a specific colouring, when the two cultures meet in dialogue, these value systems do not merge and do not mix, each retains its unity and open integrity, while mutually enriching, forming an unsurpassed background of world culture. Despite this, due to the blurring of the traditional boundaries and mixing of the values of different cultures, individual nations may find themselves (and it is happening now) in a situation where they have to abandon, at least partially, their moral and ethical norms extrapolated from the past. This is especially true of irrational/pre-rational taboos and rituals, which can be considered today as archaism or a sign of backwardness. The rejection of standards itself is not a sign of degradation. An existential sense of freedom of the Other and love 
alone is enough - they open up knowledge about the Other, and therefore in this case it becomes clearer what actions in the society are not agreed with the principles of freedom and love in other cultures. This refusal is only the result of the implementation of the universal principles of freedom, and in the state understanding - of democracy in the current view.

V. Bibler, the developer of the doctrine of the dialogue of cultures, noted: "The cultures of Europe, Asia, and America "crowd" in the same consciousness; they cannot be placed on the "ascending" line ("higher - lower, better-worse"). The simultaneity of different cultures strikes the eye and mind, becomes a real phenomenon of an everyday life of a contemporary man. At the same time, there is a strange combination of historical, ethnographic, archaeological, art studies, and semiotic forms of the understanding and definition of culture" (Bereznitckaia, 1999, p. 222). This, according to V. Mezhuiev, is the wisdom of our time, that is, in "recognizing each culture's right to independent existence, in upholding the principle of equality of all cultures, which excludes not only any culture-centrism, but also any claim to spiritual leadership on the part of a separate culture" (Gekhinskii, 2018).

The role of retransmitters of foreign cultural experience, as well as the means of forming the readiness of different cultures to its acceptance or rejection, is better performed by direct contacts between the peoples of various countries, in particular those involved in the mass tourism industry. It is mass, or rather international tourism that makes it possible to understand the existence of different nations and the specifics of their cultural and historical heritage, which potentially becomes one of the most important means of promoting understanding, trust and goodwill among the peoples of the world. That is why the researchers define responsibility, tolerance, rejection of violence, trust, openness to participation, peace, the idea of cultural equivalence and the principle of hospitality as the ethical aspects of the dialogue of cultures, which becomes the basis of the "I-Other" relations (Nazarenko, 2003, p. 2).

Throughout the history of mankind, mass travel has always accelerated the processes of economic and cultural interaction, as well as intensified the cross-cultural communication, contributing to the integration and interpenetration of cultures, self-improvement and self-realisation of individuals, the establishment of trusting relationships, mutual understanding and tolerance between representatives of different societies. Especially when, according to J. Huizinga, the author of the concept of Homo ludens, "the legitimacy of the "friend - or enemy" approach is rejected and the claims of one's own people are not accepted as the highest norm" (Huizinga, 2011, p. 137). Therefore, tourism performs not only recreational, but also an important humanizing and integrating function, forming certain fundamental basis of global solidarity (Slobodeniuk, 2003, p. 3). It is no accident that tourism is understood as a factor of humanization of relations between the peoples (E. Slobodeniuk), the dialogue of cultures (O. Kostriukova), the method of interaction of cultures (A. Alkhutov), a practical method of elaboration of principles for cooperation at the international level (A. Karamasheva), the mediator in the intercultural and interpersonal communication (A. Korzhanova), the factor of synergy of 
cultures (Ya. Liubyvyi), a natural way for the building of bridges and the rapprochement of cultures (T. Rifai), significative modality of social and cultural change (M. Budko), etc. This vision of tourism, and this is fully applied to the international tourism, reveals its ability to be a means of forming a dialogue between cultures, a means of interaction between different cultural worlds that seek a common development of the global informative and communicative civilization.

Monologue, dialogue and polylogue are the possible ways of organizing the intercultural communication in tourism (Kuzmina, 2005). In the context of a monologue, tourist resources are exploited without taking into account local specifics and attempts to familiarize guests with the peculiarities of local culture. Dialogue provides an opportunity to understand the diversity of the world, and also through the comparison with the other cultures to better understand and explore your own culture. However, sometimes the result of a dialogue can be a conflict of cultures, which occurs as a reaction to the other unusual traditions and rules of behaviour. Under the condition of a polylogue, several cultures are involved in the interaction, and the situational character and spontaneity of such communication contributes to a kind of mutual replication of their values. These three methods of intercultural communication can occur at the ethnic, national, and civilizational levels (Kuzmina, 2005). An example of the cultural interaction at the ethnic level is ethnographic tourism, the purpose of which is to familiarize with the distinctive features of the local entities, the national level is represented by the international tourism (Kuzmina, 2005), which is actually becoming a form of the dialogue between cultures.

As one of the most important fundamental forms of mass intercultural contacts, which implies the involvement of various segments of the population, international tourism not only expands the number of channels of cultural communication, but also forms the basis of productive relations and mutual understanding between cultures (Solianyk, 2004). And by preserving cultural identity and individuality, it contributes to the mutual enrichment of cultures. So, tourism as a dialogical form of meeting of cultures, on the one hand, contributes to the activation and deepening of the cultural awareness and self-identification of the traveller, and on the other - leads to the mutual enrichment of cultures through the exchange of original cultural experiences, which in the methodological context resonates with the statement of M. Bakhtin about the result and consequences of the dialogue. According to the researcher, this is a synthesis, merging of different points of view or positions into one common, mutual enrichment of different cultures as long as preserving its own culture (Bakhtin, 1986, p. 360).

Undoubtedly, the contemporary globalized world is difficult to imagine without the direct interaction of the representatives of different cultures. Cultural dialogue is the most universal principle that ensures the self - development of cultures in space and time, which, in its turn, are the product of the dialogue - interaction, communication of people and cultures - inter alia, through international tourism. It is the latter that allows different cultures to assert themselves, declare their value dominants, and also compare and corre- 
late them with the others. At the same time, the dialogue of cultures as an intercultural communication is primarily understood as interpersonal communication, since it is a space for perception and understanding of attractors of the representatives of the local cultures and is implemented exclusively at the interpersonal level. It is no accident that E. Hall, an American anthropologist and cross-cultural researcher, considering culture a kind of iceberg, where the most important parts of culture are "under water", and the obvious - "above water", argues that a full knowledge of culture can occur only through direct contact with this culture or through interpersonal interaction (Bezuglova, 2014). It is at the interpersonal level of communication that the carriers of certain cultural values and world-view stereotypes meet, with the help of which a person perceives the surrounding realities, formulates goals and chooses appropriate patterns of behaviour. The coincidence of attractors becomes the basis for the dialogue development, as a result of which various dialogical situations arise at the personal and inter-ethnic levels - from complete denial to complete perception or selective choice of values, norms, customs and traditions of another culture.

Thus, international tourism, which has the ability to change significantly both social and cultural priorities, actually forms the skills necessary for Homo viator to coordinate interests with the representatives of other cultural worlds during inclusion in the processes of consolidated activities. "...People must learn to move beyond culture and adapt it to the era and to their own biological organism", that is, a person needs the experience of other cultures just as any culture "requires interaction with other cultures in order to survive" (Elbeshauser, 2012, pp. 26-27). As a result of the international travelling, Homo viator forms a new way of world perception and attitude, important features of which are tolerance, cosmopolitanism, internationalism, readiness and loyalty to meet with another culture, intercultural competence, and so on, which play a significant role in the formation of the dialogue of cultures.

“...social and integrating mechanisms of mutual involvement of people love, participation, friendship, solidarity, sacrifice, the desire for unity, etc. ( ... ), spatial attraction, the desire to travel, overcome borders, preserve and share with each other memories, knowledge, experience" ( ... ) are best displayed in the international tourism, and this, in V. Ionesov's opinion, in addition to all the above, contributes to "overcoming ontological alienation and generic anthropological disunity” (Ionesov, 2012). Therefore, the tourism at the interpersonal level can be understood as dialogical in its nature form of meeting of cultures, which, as noted above, deepens the processes of self-awareness and identity of the traveller, and, on the other hand, - promotes the exchange between different cultural systems, and, accordingly, the acquisition by their representatives of various authentic cultural experiences.

Therefore, tourism today - as a reflexive form of interaction, partly the one that is distant from everyday life and covers different segments of the population regardless of social status, age, education - this is actually a new mass form of communication in space and time, which forms the basis of the dialogue of cultures. The latter creates a new sociocultural reality, which com- 
bines the ethnic and national traditions of various social communities, the boundaries between the peculiarities of their existence are blurred - the interculture appears.

\section{Conclusions}

International tourism is an integrative phenomenon, a peculiar means of human inculturation, a specific form of the organization of sociocultural reality. International tourism clearly demonstrates the dominant features of contemporary world processes - globalization, informatization and related phenomena - multiculturalism, mass displacement of people, creation of new cultural communities, extraterritoriality, hospitality, freedom, cultural integration and mobility, which, in fact, make possible regular contacts between the representatives of different cultures and determine the features of intercultural communication in the current circumstances. The basis for the increased activity of international tourism and the realisation of its communicative potential is the intention of the need for hospitality, the expansion of its borders and forms. Effectively responding to rapid social changes, constantly growing human needs, and offering new ways to meet them, international tourism becomes both a factor and a kind of intercultural communication, a form and means of dialogue between cultures.

The dialogue of cultures is primarily interpersonal communication, interaction of carriers of certain cultural values, world-view stereotypes, through which a person perceives the surrounding realities. This function is realized in the best way by international tourism, which is a factor in the expansion of channels and development of intercultural communication, which through social interaction at the individual and group levels contributes to effective globalization, forms relationships of trust and understanding, coordinates the shared values of various cultural communities, and therefore is a tool for establishing a dialogue between cultures.

The prospects for further research in the sphere of international tourism are to find out the main directions and forms of its influence on the national culture and on this basis to develop specific proposals for improving the system of its development, as well as making appropriate recommendations for strengthening of cultural policy in Ukraine.

\section{References}

Alkhutov, A. V. (2009). Turizm kak sposob vzaimodeistviia kultur [Tourism as a way of interaction of cultures]. (Abstract of PhD Dissertation). Krasnodar State University of Culture and Arts, Krasnodar [in Russian].

Apanasiuk, L. A., \& Egorova, E. N. (2017). Mezhdunarodnaia turistskaia deiatelnost $\mathrm{v}$ razvitii mezhkulturnoi kommunikatcii [International tourism activities in the development of intercultural communication]. In S. V. Dusenko, \& N. L. Avilova (Eds.), Sovremennye tendentcii i aktualnye voprosy razvitiia turizma i gostinichnogo biznesa $v$ Rossii [Current Trends and Topical Issues in the Development of Tourism and 
Hotel Business in Russia], Proceedings of the International Scientific and Practical Conference (pp. 184-189). RGUFKSMiT [in Russian].

Bakhtin, M. M. (1986). Estetika slovesnogo tvorchestva [Aesthetics of verbal creativity]. Iskusstvo [in Russian].

Bereznitckaia, N. L. (1999). Turizm kak faktor mezhkulturnoi kommunikatcii [Tourism as a factor of intercultural communication]. (PhD Dissertation). St. Petersburg [in Russian].

Bezuglova, N. P. (2014). Chelovek i kultura: svoboda ili zavisimost? [Man and culture: freedom or dependence?]. Culture and education, 1(12), 48-51 [in Russian].

Bibler, V. S. (1991). Mikhail Mikhailovich Bakhtin, ili Poetika i kultura [Mikhail Mikhailovich Bakhtin, or Poetics and Culture]. Progress [in Russian].

Bila knyha z mizhkulturnoho dialohu "Zhyty razom u rivnosti ta hidnosti" [White Paper on Intercultural Dialogue "Living Together in Equality and Dignity"]. (2010). Oranta [in Ukrainian].

Bogdanova, S. (2005). Kommunikatcionnye tekhnologii v turizme [Communication technology in tourism]. Turizm: praktika, problemy, perspektivy, 11, 40-41 [in Russian].

Budko, M. (2010). Turizm kak signifikativnaia modalnost sotciokulturnykh izmenenii [Tourism as an indicative modality of sociocultural changes]. Nierówności społeczne a wzrost gospodarczy. Spójność społeczno-ekonomiczna a modernizacja gospodarki, 16, 468-481 [in Russian].

Elbeshauser, H. (2012). Cultures of knowledge and expansive learning in a runaway-world. Philosophy of communication: philosophy, psychology, social communication, 5, 22-29. https://static-curis.ku.dk/portal/files/113192856/ Kopiaftidsskriftsartikel.pdf [in English].

Gekhinskii, E. (Comp.). (2018). Slovo mudrosti. Aforizmy, razmyshleniia, nastavleniia [A word of wisdom. Aphorisms, reflections, instructions] (Pt. 3). Ridero [in Russian].

webmaster. (2017, October 16). Taleb Rifai: vliianie turizma na sotcialnuiu transformatciiu [Taleb Rifai: The Impact of Tourism on Social Transformation]. Caribbean news digital. https://www.cndrussian.com/ru/noticia/taleb-rifaivliyanie-turizma-na-sotsialnuyu-transformatsiyu [in Russian].

Huizinga, J. (2011). Homo ludens. Chelovek igraiushchii [Homo ludens. The playing man]. Publishing House of Ivan Limbach [in Russian].

Ionesov, V. I. (2012). Modeli transformatcii kultury: tipologiia perekhodnogo protcessa [Culture Transformation Models: A Transition Typology]. (Doctoral Dissertation). St. Petersburg State Institute of Culture, St. Petersburg [in Russian].

Karamasheva, A. A. (2004). Kulturnyi turizm i ego znachenie v sotciokulturnom razvitii regionov $v$ usloviiakh globalizatcii [Cultural tourism and its importance in the sociocultural development of regions in the context of globalization]. (PhD Dissertation). Russian Presidential Academy of National Economy and Public Administration, Moscow [in Russian].

Korzhanova, A. A. (2011). Turizm kak sotciokulturnyi resurs razvitiia sovremennoi Rossii [Tourism as a sociocultural resource for the development of modern Russia]. (Abstract of PhD Dissertation). Moscow State Pedagogical University, Moscow [in Russian].

Kostriukova, O. (2012). Turizm kak effektivnyi instrument dialoga kultur i tcivilizatcii $\mathrm{v}$ sovremennom mire [Tourism as an effective tool for the dialogue of cultures and 
civilizations in the modern world]. Universities for Tourism and Service Association Bulletin, 3, 28-34 [in Russian].

Kuzmina, E. M. (2005). Turizm kak sposob vzaimodeistviia kultur [Tourism as a way of interaction of cultures]. (PhD Dissertation). The Tyumen State Institute of Culture, Tyumen [in Russian].

Liubyvyi, Ya. V. (2004). Turystska diialnist yak chynnyk hlobalnoi synerhii kultur [Tourism as a factor of global synergy of cultures]. In V. S. Pazenok, \& V. K. Fedorchenko (Eds.), Filosofiia turyzmu [Philosophy of Tourism] (Pt. 1). Kondor. http://infotour. in.ua/filotur18.htm [in Ukrainian].

Lyzin, A. (2005). Mezhkulturnaia kommunikatciia v turizme i ee osobennosti [Intercultural communication in tourism and its features]. Turizm: praktika, problemy, perspektivy, 5, 26-27 [in Russian].

Moshniaga, E. V.(2011). Kontceptnoe prostranstvo mezhkulturnoi kommunikatcii v sisteme mezhdunarodnogo turizma [The conceptual space of intercultural communication in the system of international tourism]. (Doctoral Dissertation). Moscow University for the Humanities, Moscow [in Russian].

Nazarenko, O. A. (2003). Etychni aspekty dialohichnykh kontseptsii kultury [Ethical aspects of dialogical concepts of culture]. (Abstract of PhD Dissertation). Taras Shevchenko National University of Kyiv, Kyiv [in Ukrainian].

Osadchii, A.V. (2001). "Vzaimodeistvie kultur" kak poniatie sovremennoi kulturologii ["Interaction of cultures" as a concept of modern cultural studies]. (PhD Dissertation). Moscow [in Russian].

Slobodeniuk, E. V. (2003). Turyzm yak chynnyk humanizatsii vidnosyn mizh narodamy [Tourism as a factor in the humanization of relations between peoples]. (Abstract of $\mathrm{PhD}$ Dissertation). H. Skovoroda Institute of Philosophy, Kyiv [in Ukrainian].

Solianyk, S. (2004). Sotsiokulturni komunikatsii v turyzmi [Sociocultural communications in tourism]. In V. S. Pazenok, \& V. K. Fedorchenko (Eds.), Filosofiia turyzmu [Philosophy of Tourism] (Pt.1). Kondor. https://tourlib.net/books_ukr/ filotur29.htm [in Ukrainian].

\section{МІЖНАРОДНИЙ ТУРИЗМ ЯК ФОРМА І ЗАСІБ ДІАЛОГУ КУЛЬТУР}

Красовський Сергій Олександрович

Викладач,

ORCID:0000-0001-9314-7594, krasovskiis@gmail.com,

Київський національний університет культури і мистецтв, Київ, Україна

Мета статті - виявити роль і значення міжнародного туризму у процесі діалогу культур. Методологія дослідження грунтується на застосуванні загальнонаукових методів, а також діяльнісного та системного підходів, які дали змогу опрацювати наукові публікації з означеної проблеми. Наукова новизна полягає у аналітичному оцінюванні ролі і значення міжнародного туризму у процесі діалогу культур. Зокрема, 
наголошено, що міжнародний туризм у сучасному глобалізованому світі стає одним iз найбільш ефективних способів розширення взаємодії представників різних культур, практичним методом вироблення принципів співпраці на міжнародному рівні. Висновки. Міжнародний туризм як своєрідний засіб інкультурації людини виразно демонструє домінуючі ознаки сучасних світових процесів, зокрема мультикультуралізму, масового переміщення людей, творення нових культурних спільнот, культурної інтеграції та мобільності. Ці процеси не лише уможливлюють регулярні контакти між представниками різних культур, а й визначають особливості міжкультурної комунікації. Дієво реагуючи на швидкоплинні суспільні зміни, постійно зростаючі потреби людини, пропонуючи нові шляхи їх задоволення, міжнародний туризм стає і чинником, і своєрідним різновидом міжкультурної комунікації, формою і засобом діалогу культур. Міжнародний туризм ефективно реалізує функцію міжособистісного комунікування, взаємодії носіїв певних культурних цінностей і світоглядних стереотипів. Міжнародний туризм формує відносини довіри та взаєморозуміння, координує спільні цінності різних культурних спільнот, а відтак $€$ інструментом встановлення діалогу між культурами. Вищевикладене дає підстави стверджувати, що ефективність міжнародного туризму, який сьогодні сприймається уже не лише як спосіб забезпечення дозвіллєвої діяльності людини, полягає і в релаксації, і в самореалізації індивіда, його адаптації до змінюваних реалій оточуючого світу.

Ключові слова: культура; діалог культур; міжнародний туризм; міжкультурна комунікація.

\section{МЕЖДУНАРОДНЫЙ ТУРИЗМ КАК ФОРМА И СРЕДСТВО ДИАЛОГА КУЛЬТУР}

Красовский Сергей Александрович

Преподаватель,

ORCID:0000-0001-9314-7594, krasovskiis@gmail.com, Киевский национальный университет культуры и искусств, Киев, Украина

Цель статьи - выявить роль и значение международного туризма в процессе диалога культур. Методология исследования основана на применении общенаучных методов, а также деятельностного и системного подходов, которые позволили изучить научные публикации по обозначенной проблеме. Научная новизна заключается в аналитической оценке роли и значения международного туризма в процессе диалога культур. В частности, отмечено, что международный туризм в современном глобализированном мире становится одним из самых эффективных способов расширения взаимодействия представителей разных культур, практическим методом выработки принципов сотрудничества на международном уровне. Выводы. Международный туризм как своеобразное средство инкультурации человека отчетливо демонстрирует доминирующие признаки современных мировых процессов, в частности мультикультурализма, массового перемещения людей, создания новых 
культурных сообществ, культурной интеграции и мобильности. Эти процессы не только делают возможными регулярные контакты между представителями различных культур, но и определяют особенности межкультурной коммуникации. Действенно реагируя на сиюминутные изменения в обществе, постоянно растущие потребности человека, предлагая новые пути их удовлетворения, международный туризм становится и фактором, и своеобразной разновидностью межкультурной коммуникации, формой и средством диалога культур. Международный туризм эффективно реализует функцию межличностного коммуницирования, взаимодействия носителей определенных культурных ценностей и мировоззренческих стереотипов. Международный туризм формирует отношения доверия и взаимопонимания, координирует общие ценности различных культурных сообществ, а поэтому является инструментом установления диалога между культурами. Вышеизложенное позволяет утверждать, что эффективность международного туризма, который сегодня воспринимается уже не только как способ обеспечения досуговой деятельности человека, заключается и в релаксации, и в самореализации индивида, его адаптации к изменяющимся реалиям окружающего мира.

Ключевые слова: культура; диалог культур; международный туризм; межкультурная коммуникация. 